\title{
PALM ROOT GROWTH AND IMPLICATIONS FOR TRANSPLANTING
}

\author{
By D.R. Hodel' ${ }^{1}$ D.R. Pittenger ${ }^{2}$, and A.J. Downer ${ }^{3}$
}

\begin{abstract}
Palms need active root and shoot growth to establish quickly after transplanting. For many palm species, roots grow most abundantly during warmer months and occur within $30 \mathrm{~cm}$ (12 in.) of the trunk. Thus, palms can be transplanted year-round in warm regions where air and soil temperatures are nearly always sufficient to ensure adequate root and shoot growth. However, in regions with cool seasons, palms are best transplanted at the beginning of the warm season. For most species, root balls with a $30 \mathrm{~cm}$ (12 in.) radius from the trunk and $30 \mathrm{~cm}$ (12 in.) deep are adequate because they capture over half the roots. The few species that must grow nearly all their new roots from the trunk after transplanting need a root ball only large enough to protect the root initiation zone, about $15 \mathrm{~cm}$ (6 in.) out from the trunk. Species that grow about $30 \%$ or more of their roots below $30 \mathrm{~cm}$ (12 in.) deep would probably benefit from a deeper root ball, about $60 \mathrm{~cm}$ (24 in.) deep.
\end{abstract}

Key Words. Palms; transplanting; time of year; root ball size; root growth; root initiation zone.

Palm trees are high-value and increasingly common components of landscapes wherever they can be grown. Large, older specimens are in great demand and command a premium price. They are usually dug and removed from existing landscape sites or from a commercial nursery field, transported, and replanted at another site, creating an instant mature landscape.

Specimen palms are relatively easy to transplant compared to broad-leaved and coniferous trees. A relatively small root ball is necessary when transplanting most palms because, as monocots, they have an adventitious root system composed of numerous fibrous primary (first-order) roots that grow independently and periodically from the root initiation zone (RIZ), the area at the base of the stem or trunk near or at ground level from which new roots grow (Tomlinson 1990). In California and the southwestern United States, it is standard industry practice for a root ball to extend from the trunk only about 15 to $30 \mathrm{~cm}$ ( 6 to 12 in.) when transplanting palms up to $20 \mathrm{~m}(60 \mathrm{ft})$ tall with trunks 30 to $100 \mathrm{~cm}$ (12 to 39 in.) in diameter. Generally, transplanted palms will establish as long as they grow new roots in a timely manner.

Despite the ease of transplanting palms, a significant number do not survive, or they require an inordinate length of time to establish. Thirty percent or more of palms in some installations fail to establish (Meerow 2000). Rapid growth of new roots from the RIZ and/or regrowth of roots cut during transplanting are critical for successful establishment. While there are many factors affecting palm root regeneration and successful transplanting, the time of year and root ball size are among the most important.

There is limited research-based information on the seasonality of palm root growth and root ball size as they relate to root growth. Nearly all the information was developed for a few species in Florida, U.S., which has a warm, humid climate-unlike palm-growing regions with a Mediterranean climate where winters are cool and with little rain and summers are warm to hot and rainless.

\section{PREVIOUS WORK}

Although palms are transplanted year-round in some areas, the traditional recommendation is to transplant them during the warmer times of the year (Donselman 1981; Hodel 1995, 1996, 1997; Broschat and Meerow 2000). Broschat (1998) reported that palm root and shoot growth are greatest when soil and air temperatures are highest. He suggested that palms could be transplanted at any season in tropical areas and southern Florida, because root and shoot growth occurred year-round. However, he suggested that winter planting was not advisable in cooler climates.

In preliminary studies, Hodel et al. (1998) and Pittenger et al. (2000) reported that, in southern California, root growth of most palms tended to be highest during the warmer months from spring through fall. However, the landscape industry in southern California transplants especially hardy palms, such as Chamaerops humilis (European or Mediterranean fan palm), Phoenix canariensis (Canary Island date palm), P. dactylifera (date palm), Syagrus romanzoffiana (queen palm), Trachycarpus fortunei (Chinese windmill palm), Washingtonia filifera (California fan palm), and W. robusta (Mexican fan palm) year-round to keep pace with development and demand, although the success rate is variable.

The optimal root ball size when transplanting palms has been the subject of much debate and speculation. Traditional recommendations range from nearly no root ball to one as big as possible. Broschat and Donselman (1984a, 1984b) reported that palm root balls commonly extend $45 \mathrm{~cm}$ (18 in.) out from the trunk because most roots cut during transplanting die and must be replaced by roots originating from the trunk. How- 
ever, Tomlinson (1961) had noted that severed palm roots usually regrow from just proximal of the cut.

Understanding how palm roots respond to cutting is critical to determining the optimal root ball size for successful transplanting (Broschat and Meerow 2000). In Florida on field-grown palms, Broschat and Donselman (1984a, 1984b, 1990) reported that the response of roots to cutting varies among species. In Phoenix reclinata (Senegal date palm), Roystonea regia (royal palm), Syagrus romanzoffiana, and Washingtonia robusta, some severed roots regrow from just proximal of the cut and, generally, the percentage of regrown roots increases the farther the roots are cut from the trunk. Thus, they advised that a relatively large root ball was important for root regrowth and successful establishment of these species. In contrast, they discovered in Cocos nucifera that about half of severed roots regrow regardless of the distance they are cut from the trunk, suggesting that root ball size was less important for this species. However, another interpretation of their data shows that a root ball extending $15 \mathrm{~cm}$ ( 6 in.) out from the trunk would be sufficient for nearly all these species because about half or more of all new roots are found within that distance.

In Sabal palmetto, Broschat and Donselman (1984a, 1984b) stated that nearly all cut roots die back to the trunk and nearly all new roots grow from the RIZ. Because this species must grow an entirely new root system from the RIZ to establish successfully, they recommended a root ball only large enough to protect the RIZ.

Phoenix reclinata, Roystonea regia, and Washingtonia robusta grow large numbers of new roots from the RIZ, while Cocos nucifera (coconut palm) and Syagrus romanzoffiana grow relatively few (Broschat and Donselman 1984a, 1984b). In the latter two species, however, the number of cut roots that regrow is large and surpassed the number of new roots that grow from the RIZ. Phoenix dactylifera offshoots responded similarly, with over two-thirds of new root growth originating from roots severed during removal from the mother palm, all of which were cut only 2 to $10 \mathrm{~cm}$ (1 to 4 in.) long (Hodel and Pittenger 2003).

Minimum recommended root ball sizes (measured by the distance out from the trunk) are 15 to $30 \mathrm{~cm}$ (6 to 12 in.) for Syagrus romanzoffiana, 30 to $60 \mathrm{~cm}$ (12 to 24 in.) for Washingtonia robusta, and at least $60 \mathrm{~cm}$ (24 in.) for Phoenix reclinata and Roystonea regia, because there is little regrowth of roots cut shorter than these lengths (Broschat and Donselman 1984a, 1984b, 1990). Root balls for the last three species are larger in order to encompass a sufficient percentage of regrown roots. Root pruning is recommended 2 to 3 months prior to transplanting for these species in order to stimulate a large number of new roots to grow from the RIZ so that a smaller root ball could be taken (Broschat and Donselman 1984a, 1984b, 1987, 1990). Perhaps the most important interpretation of Broschat and
Donselman (1984a, 1984b) was that most of a palm's roots occur within $30 \mathrm{~cm}$ (12 in.) of the trunk.

Root pruning prior to transplanting could benefit species that grow most of their new roots from regrown cut roots because it would shorten or eliminate the length of time for the cut roots to regrow after transplanting (Broschat and Donselman 1987). Later, Meerow (1992) and Broschat and Meerow (2000) placed less emphasis on root pruning but said it might be useful in some cases, although they presented no supporting data.

More recently, the ability of cut palm roots to regrow as a determinate of root ball size has lost favor in transplanting guidelines. Meerow (1992), Meerow and Broschat (1992), and Broschat and Meerow (2000) now simply recommend a root ball extending at least $20 \mathrm{~cm}$ (8 in.) out from the trunk for single-stemmed species up to $5 \mathrm{~m}(15 \mathrm{ft})$ tall and at least $30 \mathrm{~cm}$ (12 in.) out from the trunk for larger or multistemmed species. In species where few or no severed roots survive, such as Sabal palmetto, they recommend a root ball 10 to $15 \mathrm{~cm}$ (4 to $6 \mathrm{in}$.) out from the trunk, just large enough to protect the RIZ. However, no supporting data are offered for these newer recommendations.

In some cases, plant maturity may affect transplant success. In Chamaedorea elegans and Phoenix roebelinii, root growth is dependent on the presence of a RIZ that does not form until the palm stem attains its maximum diameter and begins to elongate vertically (Broschat and Donselman 1990). However, in Phoenix dactylifera (Hodel and Pittenger 2003) and Phoenix canariensis and Syagrus romanzoffiana (Hodel et al. 2003), the RIZ develops and becomes active at a much earlier stage, well before the stem attains its maximum diameter and elongates vertically.

These conflicting findings and interpretations raise questions about the importance of root ball size, regrowth of severed roots, and growth of new roots from the trunk (RIZ) to successful transplanting. Perhaps time of year and total number of new roots produced, regardless of their origin, are as or more important than root ball size or the origin of new roots. The objective of this study was to assess the seasonality and distribution of palm root growth in 16 species of ornamental palms in a Mediterranean climate to provide the landscape industry with clear, precise information about the optimal time of year and root ball size for transplanting palms.

\section{METHODS}

From June 1997 through December 2000, we conducted a field study with mature, established specimens of 16 palm species (Table 1) at The Los Angeles County Arboretum \& Botanic Garden in Arcadia, California, U.S. This site is about $25 \mathrm{~km}$ (16.5 mi) east of Los Angeles and has a Mediterranean climate and a sandy clay loam soil. The palms ranged from 30 to 50 years of age according to arboretum accession records and were 2 to $10 \mathrm{~m}$ (6 to $30 \mathrm{ft}$ ) tall. 
Table 1. Palm species used in root growth study, The Los Angeles County Arboretum \& Botanic Garden, Arcadia, California, 1997-2000.

\begin{tabular}{lll}
\hline Species & Common name & Origin \\
\hline Archontophoenix cunninghamiana & king palm & southeastern Australia \\
Brahea edulis & Guadalupe palm & Guadalupe Island, Mexico \\
Butia capitata & pindo palm, jelly palm & northern Argentina, southern Brazil \\
Caryota mitis & clustered fishtail palm & southeastern Asia, Malaysia, Indonesia \\
Chamaerops humilis & European fan palm & southern Europe, northern Africa \\
Livistona chinensis & Chinese fan palm & southern Japan, southern China \\
Livistona decipiens & ribbon fan palm & eastern Australia \\
Phoenix canariensis & Canary Island date palm & Canary Islands \\
Phoenix reclinata & Senegal date palm & tropical Africa \\
Rhapidophyllum hystrix & needle palm & southeastern United States \\
Sabal etonia & palmetto, cabbage palm & southeastern United States \\
Serenoa repens & saw palmetto & southeastern United States \\
Syagrus romanzoffiana & queen palm & northern Argentina, southern Brazil \\
Trachycarpus fortunei & Chinese windmill palm & southern China \\
\hline
\end{tabular}

Using a gasoline-powered trencher, we dug a trench 15 $\mathrm{cm}$ wide $\times 60 \mathrm{~cm}$ deep $\times 90 \mathrm{~cm}$ long $(6 \times 12 \times 36$ in. $)$ in June on a tangent from the base of each of the three, single-tree replicates of each species. Using a spade and shovel, we manually dug trenches on three additional, single-tree replicates of two species, Archontophoenix cunninghamiana and Livistona chinensis, to determine whether roots cut in this method responded differently than those cut by the trencher. We backfilled each trench with perlite and covered it with 2.5 to $7.5 \mathrm{~cm}$ (1 to $3 \mathrm{in}$.) of mulch. We adapted our technique from that of Broschat and Donselman (1984a, 1984b, 1990).

We divided each trench into four zones: 15, 30, 60, and $90 \mathrm{~cm}(6,12,24$, and $36 \mathrm{in}$.) from the trunk base. Each of these zones was divided into two depths of 0 to $30 \mathrm{~cm}$ ( 0 to $12 \mathrm{in}$.) and 30 to $60 \mathrm{~cm}$ (12 to $24 \mathrm{in}$.), resulting in a total of eight trench zones. Zones A, B, C, and D were the upper depth zones, while E, F, G, and H were the lower depth zones.

Palms were well irrigated throughout the study to ensure the perlite was kept moist. At 3-month intervals over the next 3 years, we re-excavated each trench to harvest and count all roots, regardless of size or origin, growing into each of the eight trench zones and determined total mean root number per zone. We oven dried harvested roots at $105^{\circ} \mathrm{C}\left(221^{\circ} \mathrm{F}\right)$ until constant weight was achieved and determined total mean root dry weight per zone. We divided root dry weight by root number to calculate mean individual root size (weight per root) per zone. At each 3-month harvest, we recorded the soil temperature using a thermometer placed $10 \mathrm{~cm}$ (4 in.) deep in the trench. Although we did not determine the origin of each of the new roots, we made general observations about the presence of regrown severed roots.

Because rapid root regrowth is critical to transplant success, we combined data from each upper zone with its corresponding lower zone for analysis. Thus, each palm's data from zone A were combined with E, B with F, C with G, and D with $\mathrm{H}$ to determine the lateral root distribution. We also compared the combined four upper zones with the combined four lower zones to determine the root vertical distribution.

The experimental design was completely randomized with each of the 16 species represented by three, healthy, similarsized and -aged, single-tree replications. We analyzed seasonality and lateral distribution of roots by one-way ANOVA and separated means using least significant difference (LSD). We analyzed vertical root distribution by paired t-tests.

\section{RESULTS}

Mean annual root growth or numbers varied among species over the 3 years of our study (Table 2). There was no significant difference in new root numbers between machinedug and hand-dug trenches (data not shown). Species with consistently high numbers, over 50 roots annually, include Livistona decipiens, Phoenix canariensis, P. reclinata, Syagrus romanzoffiana, Trachycarpus fortunei, T. wagnerianus, and Washingtonia robusta - the latter the highest, with over 150 roots. Species with consistently low numbers, fewer than 20 roots annually, include Archontophoenix cunninghamiana, Brahea edulis, Butia capitata, Chamaerops humilis, and Serenoa repens, with the Brahea the lowest-typically only one to two annually.

Annual root numbers for a species varied annually, but differences were significant in only four species (Table 2). Root numbers decreased after year 1 in Brahea edulis and Livistona chinensis but increased in year 3 in Phoenix canariensis. Root numbers in Chamaerops humilis had a unique low-high-low pattern over 3 years.

Mean root weight did not differ annually except in Brahea edulis and Livistona chinensis, which decreased over time, and in Phoenix canariensis, which increased over time (Table 2). Mean root size differed annually only in Butia 
Table 2. Mean total root numbers (n), mean total root dry weights (g), and mean individual root size (g/n) of 16 species in all trench zones by year, The Los Angeles County Arboretum \& Botanic Garden, Arcadia, California, 1997-2000.

\begin{tabular}{|c|c|c|c|}
\hline Species & Number $(n)$ & Weight (g) & Size $(g / n)$ \\
\hline $\begin{array}{l}\text { Archontophoenix cunninghamiana } \\
\text { 1997-1998 } \\
\text { 1998-1999 } \\
\text { 1999-2000 }\end{array}$ & $\begin{array}{l}17.4 \\
19.4 \\
21.9\end{array}$ & $\begin{array}{r}9.5 \\
18.8 \\
15.1\end{array}$ & $\begin{array}{l}0.516 \\
0.787 \\
0.712\end{array}$ \\
\hline $\begin{array}{l}\text { Brahea edulis } \\
1997-1998 \\
1998-1999 \\
1999-2000\end{array}$ & $\begin{array}{r}15.6 \mathrm{a} \\
1.3 \mathrm{~b} \\
1.8 \mathrm{~b}\end{array}$ & $\begin{array}{l}2.7 \mathrm{a} \\
0.5 \mathrm{~b} \\
1.0 \mathrm{~b}\end{array}$ & $\begin{array}{l}0.244 \\
0.109 \\
0.234\end{array}$ \\
\hline $\begin{array}{l}\text { Butia capitata } \\
1997-1998 \\
1998-1999 \\
1999-2000\end{array}$ & $\begin{array}{l}11.2 \\
12.0 \\
25.2\end{array}$ & $\begin{array}{l}6.4 \\
4.0 \\
9.4\end{array}$ & $\begin{array}{l}0.548 \mathrm{a} \\
0.191 \mathrm{ab} \\
0.343 \mathrm{~b}\end{array}$ \\
\hline $\begin{array}{l}\text { Caryota mitis } \\
1997-1998 \\
1998-1999 \\
1999-2000\end{array}$ & $\begin{array}{l}34.3 \\
31.1 \\
18.5\end{array}$ & $\begin{array}{l}7.9 \\
4.5 \\
2.5\end{array}$ & $\begin{array}{l}0.384 \\
0.112 \\
0.129\end{array}$ \\
\hline $\begin{array}{l}\text { Chamaerops humilis } \\
\text { 1997-1998 } \\
1998-1999 \\
1999-2000\end{array}$ & $\begin{array}{l}13.8 \mathrm{~b} \\
28.0 \mathrm{a} \\
15.0 \mathrm{~b}\end{array}$ & $\begin{array}{l}2.5 \\
6.4 \\
2.3\end{array}$ & $\begin{array}{l}0.121 \\
0.176 \\
0.150\end{array}$ \\
\hline $\begin{array}{l}\text { Livistona chinensis } \\
\text { 1997-1998 } \\
\text { 1998-1999 } \\
\text { 1999-2000 }\end{array}$ & $\begin{array}{l}46.8 \mathrm{a} \\
16.0 \mathrm{~b} \\
22.6 \mathrm{~b}\end{array}$ & $\begin{array}{r}42.4 \mathrm{a} \\
8.4 \mathrm{~b} \\
17.7 \mathrm{~b}\end{array}$ & $\begin{array}{l}0.798 \\
0.518 \\
0.635\end{array}$ \\
\hline $\begin{array}{l}\text { Livistona decipiens } \\
1997-1998 \\
1998-1999 \\
1999-2000\end{array}$ & $\begin{array}{r}63.3 \\
65.5 \\
109.8\end{array}$ & $\begin{array}{l}30.4 \\
28.7 \\
47.4\end{array}$ & $\begin{array}{l}0.413 \\
0.292 \\
0.255\end{array}$ \\
\hline $\begin{array}{l}\text { Phoenix canariensis } \\
\text { 1997-1998 } \\
\text { 1998-1999 } \\
\text { 1999-2000 }\end{array}$ & $\begin{array}{r}49.9 \mathrm{~b} \\
56.7 \mathrm{~b} \\
185.7 \mathrm{a}\end{array}$ & $\begin{array}{c}20.2 \mathrm{~b} \\
35.9 \mathrm{ab} \\
104.4 \mathrm{a}\end{array}$ & $\begin{array}{l}0.356 \\
0.562 \\
0.453\end{array}$ \\
\hline $\begin{array}{l}\text { Phoenix reclinata } \\
1997-1998 \\
1998-1999 \\
1999-2000\end{array}$ & $\begin{array}{r}86.6 \\
122.0 \\
151.6\end{array}$ & $\begin{array}{r}37.5 \\
67.4 \\
116.1\end{array}$ & $\begin{array}{l}0.425 \\
0.379 \\
0.573\end{array}$ \\
\hline $\begin{array}{l}\text { Rhapidophyllum hystrix } \\
\text { 1997-1998 } \\
\text { 1998-1999 } \\
\text { 1999-2000 }\end{array}$ & $\begin{array}{l}32.3 \\
30.7 \\
18.0\end{array}$ & $\begin{array}{l}3.7 \\
4.7 \\
3.8\end{array}$ & $\begin{array}{l}0.096 \\
0.156 \\
0.141\end{array}$ \\
\hline $\begin{array}{l}\text { Sabal etonia } \\
\text { 1997-1998 } \\
1998-1999 \\
1999-2000\end{array}$ & $\begin{array}{l}20.4 \\
19.3 \\
30.5\end{array}$ & $\begin{array}{l}4.3 \\
4.8 \\
6.2\end{array}$ & $\begin{array}{l}0.218 \\
0.248 \\
0.239\end{array}$ \\
\hline $\begin{array}{l}\text { Serenoa repens } \\
1997-1998 \\
1998-1999 \\
1999-2000\end{array}$ & $\begin{array}{l}18.0 \\
19.3 \\
30.5\end{array}$ & $\begin{array}{l}5.3 \\
6.6 \\
4.3\end{array}$ & $\begin{array}{l}0.423 \\
0.217 \\
0.181\end{array}$ \\
\hline
\end{tabular}

Means in the same column within a species followed by a different letter are significantly different according to LSD, $P<0.05$. 
Table 2 (continued). Mean total root numbers (n), mean total root dry weights (g), and mean individual root size (g/n) of 16 species in all trench zones by year, The Los Angeles County Arboretum \& Botanic Garden, Arcadia, California, 1997-2000.

\begin{tabular}{lccc}
\hline Species & Number $(n)$ & Weight $(\mathrm{g})$ & Size $(\mathrm{g} / \mathrm{n})$ \\
\hline Syagrus romanzoffiana & & & \\
1997-1998 & 136.4 & 36.5 & 0.243 \\
1998-1999 & 96.8 & 44.2 & 0.267 \\
1999-2000 & 67.5 & 21.3 & 0.229 \\
Trachycarpus fortunei & & & \\
1997-1998 & 76.8 & 5.9 & 0.090 \\
1998-1999 & 31.8 & 2.9 & 0.043 \\
1999-2000 & 69.3 & 8.7 & 0.076 \\
Trachycarpus wagnerianus & & & \\
1997-1998 & 78.8 & 16.9 & $0.189 \mathrm{a}$ \\
1998-1999 & 111.2 & 15.0 & $0.116 \mathrm{~b}$ \\
1999-2000 & 124.6 & 24.4 & $0.113 \mathrm{~b}$ \\
Washingtonia robusta & & & \\
1997-1998 & 154.0 & 22.2 & 0.144 \\
1998-1999 & 174.1 & 21.5 & 0.083 \\
1999-2000 & 161.4 & 17.3 & 0.077 \\
\hline
\end{tabular}

Means in the same column within a species followed by a different letter are significantly different according to LSD, $P<0.05$.

capitata and Trachycarpus wagnerianus, which decreased over time (Table 2).

Although not counted and analyzed, we observed that all species had severed roots that regrew, some rather prolifically, with up to several new roots per severed root.

\section{Seasonality of Growth}

Soil temperatures varied seasonally, averaging $10^{\circ} \mathrm{C}\left(50^{\circ} \mathrm{F}\right)$ in December, $13^{\circ} \mathrm{C}\left(55^{\circ} \mathrm{F}\right)$ in March, $20^{\circ} \mathrm{C}\left(68^{\circ} \mathrm{F}\right)$ in June, and $21^{\circ} \mathrm{C}\left(70^{\circ} \mathrm{F}\right)$ in September. Mean root numbers were significantly higher in the warmer months (spring, summer, and/or fall) for most species (Table 3). Only Brahea edulis, Chamaerops humilis, and Livistona chinensis lacked distinct seasonality, although they tended to have higher numbers in the summer and fall. Maximum mean warm-season root numbers ranged from about 11 in Brahea edulis to 329 in Washingtonia robusta. In most species, maximum warmseason numbers were 70 or less, although they were well over 200 in six species (Livistona decipiens, Phoenix canariensis, P. reclinata, Syagrus romanzoffiana, Trachycarpus wagnerianus, and W. robusta).

Seven species (Archontophoenix cunninghamiana, Livistona decipiens, Phoenix canariensis, Sabal etonia, Serenoa repens, Syagrus romanzoffiana, and Trachycarpus wagnerianus) had highest root numbers in the summer, most with two to ten times as many roots in the summer as in other seasons.

Six species had highest root numbers in two or more of the warmer seasons: Butia capitata, Caryota mitis, and Rhapidophyllum hystrix in the summer and fall; Phoenix reclinata and Washingtonia robusta in the spring and summer; and Trachycarpus fortunei in the spring, summer, and fall.

Mean winter numbers were low in all species except Washingtonia robusta, which averaged nearly 28 roots. Caryota mitis and Serenoa repens averaged less than one root in the winter, the lowest among all species.

Mean root weight increased during the warmer seasons except in Brahea edulis and Livistona chinensis, which had no seasonal differences (Table 3). Mean root size increased during the warmer seasons in half the species: Archontophoenix cunninghamiana, Livistona decipiens, Phoenix canariensis, Rhapidophyllum hystrix, Serenoa repens, Syagrus romanzoffiana, Trachycarpus wagnerianus, and Washingtonia robusta (Table 3). The remaining species had no seasonal differences in root size.

\section{Root Distribution}

Lateral Distribution. With the exception of Rhapidophyllum hystrix, mean new root numbers were highest in the zones closest to the trunk and lowest in the zones farthest away (Table 4). All species had at least 50\% of growth within 30 $\mathrm{cm}$ (12 in.) of the trunk, and three (Livistona decipiens, Trachycarpus fortunei, and Washingtonia robusta) had more than $50 \%$ of growth within $15 \mathrm{~cm}$ (6 in.) of the trunk.

Vertical Distribution. Mean new root numbers in 13 of the 16 species was significantly higher ( $>60 \%$ of new roots) in the combined upper zones 0 to $30 \mathrm{~cm}$ ( 0 to $12 \mathrm{in}$.) deep than in the combined lower zones 30 to $60 \mathrm{~cm}$ (12 to $24 \mathrm{in}$.) deep (Table 5). These 13 species grew at least twice as many 
Table 3. Mean total root numbers ( $n$ ), mean total root dry weights (g), and mean individual root size (g/n) of 16 species of palms in all trench zones by season, The Los Angeles County Arboretum $\&$ Botanic Garden, Arcadia, California, 1997-2000.

\begin{tabular}{|c|c|c|c|}
\hline Species and season & Number $(n)$ & Weight (g) & Size $(g / n)$ \\
\hline $\begin{array}{l}\text { Archontophoenix cunninghamiana } \\
\text { Winter (Jan.-Mar.) } \\
\text { Spring (Apr.-Jun.) } \\
\text { Summer (Jul.-Sep.) } \\
\text { Fall (Oct.-Dec.) }\end{array}$ & $\begin{array}{r}3.0 \mathrm{~b} \\
21.3 \mathrm{~b} \\
39.8 \mathrm{a} \\
14.2 \mathrm{~b}\end{array}$ & $\begin{array}{l}1.0 \mathrm{~b} \\
10.0 \mathrm{~b} \\
36.0 \mathrm{a} \\
10.9 \mathrm{ab}\end{array}$ & $\begin{array}{l}0.285 \mathrm{~b} \\
0.528 \mathrm{ab} \\
0.807 \mathrm{a} \\
0.892 \mathrm{a}\end{array}$ \\
\hline $\begin{array}{l}\text { Brahea edulis } \\
\text { Winter (Jan.-Mar.) } \\
\text { Spring (Apr.-Jun.) } \\
\text { Summer (Jul.-Sep.) } \\
\text { Fall (Oct.-Dec.) }\end{array}$ & $\begin{array}{r}2.0 \\
4.9 \\
7.2 \\
10.8\end{array}$ & $\begin{array}{l}0.6 \\
1.1 \\
2.1 \\
1.8\end{array}$ & $\begin{array}{l}0.302 \\
0.200 \\
0.499 \\
0.214\end{array}$ \\
\hline $\begin{array}{l}\text { Butia capitata } \\
\text { Winter (Jan.-Mar.) } \\
\text { Spring (Apr.-Jun.) } \\
\text { Summer (Jul.-Sep.) } \\
\text { Fall (Oct.-Dec.) }\end{array}$ & $\begin{array}{l}2.4 \mathrm{~b} \\
10.4 \mathrm{~b} \\
39.4 \mathrm{a} \\
12.1 \mathrm{ab}\end{array}$ & $\begin{array}{r}2.0 \mathrm{~b} \\
4.3 \mathrm{~b} \\
14.2 \mathrm{a} \\
5.7 \mathrm{ab}\end{array}$ & $\begin{array}{l}0.315 \\
0.503 \\
0.298 \\
0.327\end{array}$ \\
\hline $\begin{array}{l}\text { Caryota mitis } \\
\text { Winter (Jan.-Mar.) } \\
\text { Spring (Apr.-Jun.) } \\
\text { Summer (Jul.-Sep.) } \\
\text { Fall (Oct.-Dec.) }\end{array}$ & $\begin{array}{c}0.4 \mathrm{~b} \\
4.3 \mathrm{~b} \\
70.3 \mathrm{a} \\
36.8 \mathrm{ab}\end{array}$ & $\begin{array}{l}0.0 \mathrm{~b} \\
0.3 \mathrm{~b} \\
9.8 \mathrm{a} \\
9.6 \mathrm{a}\end{array}$ & $\begin{array}{l}0.067 \\
0.089 \\
0.127 \\
0.439\end{array}$ \\
\hline $\begin{array}{l}\text { Chamaerops humilis } \\
\text { Winter (Jan.-Mar.) } \\
\text { Spring (Apr.-Jun.) } \\
\text { Summer (Jul.-Sep.) } \\
\text { Fall (Oct.-Dec.) }\end{array}$ & $\begin{array}{l}13.0 \\
11.6 \\
28.7 \\
22.4\end{array}$ & $\begin{array}{l}1.6 \mathrm{~b} \\
1.4 \mathrm{~b} \\
7.8 \mathrm{a} \\
4.1 \mathrm{ab}\end{array}$ & $\begin{array}{l}0.116 \\
0.116 \\
0.189 \\
0.175\end{array}$ \\
\hline $\begin{array}{l}\text { Livistona chinensis } \\
\text { Winter (Jan.-Mar.) } \\
\text { Spring (Apr.-Jun.) } \\
\text { Summer (Jul.-Sep.) } \\
\text { Fall (Oct.-Dec.) }\end{array}$ & $\begin{array}{r}9.1 \\
29.7 \\
42.9 \\
32.1\end{array}$ & $\begin{array}{r}4.2 \\
19.5 \\
28.6 \\
39.0\end{array}$ & $\begin{array}{l}0.434 \\
0.622 \\
0.724 \\
0.822\end{array}$ \\
\hline $\begin{array}{l}\text { Livistona decipiens } \\
\text { Winter (Jan.-Mar.) } \\
\text { Spring (Apr.-Jun.) } \\
\text { Summer (Jul.-Sep.) } \\
\text { Fall (Oct.-Dec.) }\end{array}$ & $\begin{array}{r}4.4 \mathrm{~b} \\
23.5 \mathrm{~b} \\
214.4 \mathrm{a} \\
75.8 \mathrm{~b}\end{array}$ & $\begin{array}{r}1.1 \mathrm{~b} \\
3.7 \mathrm{~b} \\
101.1 \mathrm{a} \\
36.1 \mathrm{~b}\end{array}$ & $\begin{array}{l}0.217 \mathrm{~b} \\
0.222 \mathrm{~b} \\
0.445 \mathrm{a} \\
0.364 \mathrm{ab}\end{array}$ \\
\hline $\begin{array}{l}\text { Phoenix canariensis } \\
\text { Winter (Jan.-Mar.) } \\
\text { Spring (Apr.-Jun.) } \\
\text { Summer (Jul.-Sep.) } \\
\text { Fall (Oct.-Dec.) }\end{array}$ & $\begin{array}{r}7.0 \mathrm{~b} \\
78.4 \mathrm{~b} \\
241.6 \mathrm{a} \\
62.6 \mathrm{~b}\end{array}$ & $\begin{array}{r}2.2 \mathrm{~b} \\
29.2 \mathrm{~b} \\
150.9 \mathrm{a} \\
31.8 \mathrm{~b}\end{array}$ & $\begin{array}{l}0.344 \mathrm{bc} \\
0.319 \mathrm{c} \\
0.620 \mathrm{a} \\
0.544 \mathrm{ab}\end{array}$ \\
\hline $\begin{array}{l}\text { Phoenix reclinata } \\
\text { Winter (Jan.-Mar.) } \\
\text { Spring (Apr.-Jun.) } \\
\text { Summer (Jul.-Sep.) } \\
\text { Fall (Oct.-Dec.) }\end{array}$ & $\begin{array}{l}13.1 \mathrm{c} \\
151.5 \mathrm{ab} \\
229.9 \mathrm{a} \\
76.0 \mathrm{bc}\end{array}$ & $\begin{array}{r}2.8 \mathrm{~b} \\
55.3 \mathrm{~b} \\
170.4 \mathrm{a} \\
48.1 \mathrm{~b}\end{array}$ & $\begin{array}{l}0.269 \\
0.360 \\
0.601 \\
0.578\end{array}$ \\
\hline $\begin{array}{l}\text { Rhapidophyllum hystrix } \\
\text { Winter (Jan.-Mar.) } \\
\text { Spring (Apr.-Jun.) } \\
\text { Summer (Jul.-Sep.) } \\
\text { Fall (Oct.-Dec.) }\end{array}$ & $\begin{array}{r}3.7 \mathrm{~b} \\
12.1 \mathrm{~b} \\
50.8 \mathrm{a} \\
41.4 \mathrm{a}\end{array}$ & $\begin{array}{l}0.1 \mathrm{c} \\
1.6 \mathrm{c} \\
9.2 \mathrm{a} \\
5.3 \mathrm{~b}\end{array}$ & $\begin{array}{l}0.057 \mathrm{~b} \\
0.132 \mathrm{ab} \\
0.168 \mathrm{a} \\
0.141 \mathrm{a}\end{array}$ \\
\hline
\end{tabular}

Means in the same column within a species followed by a different letter are significantly different according to LSD, P<0.05. 
Table 3 (continued). Mean total root numbers $(n)$, mean total root dry weights $(\mathrm{g})$, and mean individual root size $(\mathrm{g} / \mathrm{n})$ of 16 species of palms in all trench zones by season, The Los Angeles County Arboretum \& Botanic Garden, Arcadia, California, 1997-2000.

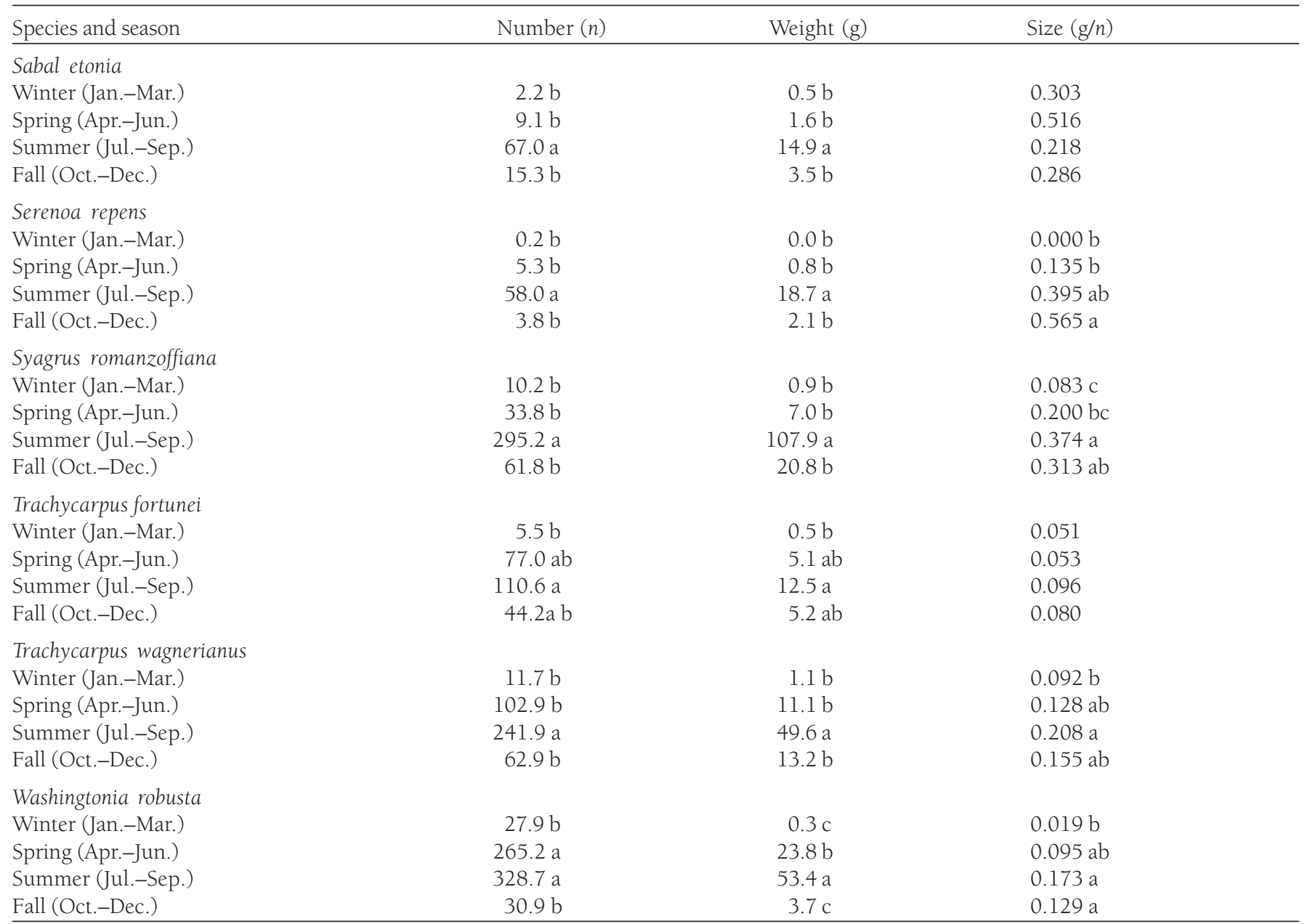

Means in the same column within a species followed by a different letter are significantly different according to LSD, $P<0.05$.

roots in the upper as in the lower zone. Brahea edulis and Trachycarpus fortunei grew nearly all their roots in the upper zone. New roots of Butia capitata, Livistona chinensis, and Syagrus romanzoffiana were evenly distributed between the upper and lower zones. Thus, in all species, at least $50 \%$ of root growth occurred in the upper $30 \mathrm{~cm}$ (12 in.) of soil.

\section{DISCUSSION}

There are large differences in root growth among palm species. Our results of seasonality of root growth support the work of Broschat (1998) and the popular belief that palm roots grow most actively in the warmest months.

Winters in California (a region with a Mediterranean climate) are sufficiently cool and long to reduce root growth in most species. Thus, the best time to transplant palms in Mediterranean climates is the late spring to early summer
(May to July in the Northern Hemisphere). Transplanting at this time provides a long, warm period that promotes root growth to ensure establishment. Late spring to early summer transplanting might be critical for rare and/or unusually valuable specimens, those species that grow relatively few roots per year, or for species that grow a preponderance of new roots in the summer.

This recommendation does not mean that certain species cannot be successfully transplanted in the fall or winter in Mediterranean climates. However, the opportunity for successful transplanting is lowest in the fall and winter and highest in the late spring to early summer, particularly for species that grow few roots in the cooler seasons. If transplanting in the fall and winter, judicious attention must be given to other factors that affect transplant success, such as digging and handling, planting depth, and irrigation. 
Table 4. Mean new root numbers and percentage (in parentheses, rounded to a whole number) of 16 palm species by lateral distance from the trunk and to $60 \mathrm{~cm}$ deep, The Los Angeles County Arboretum \& Botanic Garden, Arcadia, California, 1997-2000.

\begin{tabular}{|c|c|c|c|c|}
\hline \multirow[b]{2}{*}{ Species } & \multicolumn{4}{|c|}{ Lateral distance from trunk } \\
\hline & $0-15 \mathrm{~cm}$ & $15-30 \mathrm{~cm}$ & $30-60 \mathrm{~cm}$ & $60-90 \mathrm{~cm}$ \\
\hline Archontophoenix cunninghamiana & 6.6 a (34) & 6.3 a (32) & $4.8 \mathrm{a}(25)$ & $1.9 \mathrm{~b}(10)$ \\
\hline Brahea edulis & $3.0 \mathrm{a}(48)$ & $2.2 \mathrm{a}(35)$ & $0.8 \mathrm{~b}(13)$ & $0.3 \mathrm{~b}(4)$ \\
\hline Butia capitata & 6.7 a (42) & $5.3 \mathrm{~b}(33)$ & 3.1 c (19) & $1.1 \mathrm{~d}(7)$ \\
\hline Caryota mitis & $7.2 \mathrm{a}(26)$ & $7.4 \mathrm{a}(26)$ & 8.6 a (31) & $4.7 \mathrm{~b}(17)$ \\
\hline Chamaerops humilis & 6.2 a (37) & $4.0 \mathrm{~b}(24)$ & $3.9 \mathrm{~b}(24)$ & $2.6 \mathrm{~b}(16)$ \\
\hline Phoenix canariensis & $32.7 \mathrm{a}(34)$ & $22.5 \mathrm{~b}(23)$ & $27.1 \mathrm{ab}(28)$ & 15.2 c (16) \\
\hline Phoenix reclinata & $49.8 \mathrm{a}(40)$ & $32.4 \mathrm{~b}(26)$ & $24.2 \mathrm{~b}(19)$ & 19.2 c (15) \\
\hline Rhapidophyllum hystrix & $7.2 \mathrm{~b}(27)$ & $5.9 \mathrm{~b}(22)$ & $10.8 \mathrm{a}(40)$ & $3.1 \mathrm{c}(11)$ \\
\hline Sabal etonia & $9.4 \mathrm{a}(40)$ & $6.4 \mathrm{~b}(27)$ & $5.4 \mathrm{~b}(23)$ & 2.2 c (9) \\
\hline Serenoa repens & $7.4 \mathrm{a}(43)$ & $4.2 \mathrm{~b}(24)$ & $3.4 \mathrm{~b}(20)$ & $2.3 \mathrm{~b}(13)$ \\
\hline Syagrus romanzoffiana & 36.9 a (37) & $24.1 \mathrm{~b}(24)$ & $25.0 \mathrm{~b}(25)$ & 14.8 c (14) \\
\hline
\end{tabular}

Means in the same row followed by a different letter are significantly different according to paired t-tests between columns, $P<0.05$.

Because cool, moist winters and warm, dry, nearly rainless summers characterize Mediterranean climates, irrigation is typically required when transplanting palms in these regions. In warm, humid subtropical or tropical regions with distinct wet and dry seasons, it is best to transplant palms at the beginning of the rainy season if irrigation is lacking and landscapers are relying on rain to maintain soil moisture in the root zone at adequate levels. In many warm, humid subtropical or tropical regions, the rainy season corresponds to the warmer months of the year.

Although we did not distinguish size when we harvested and counted roots, the increase in root size during the warmer months might be reflective of an increase of new primary (first-order) roots growing from the RIZ or even regrown, severed primary roots. New and regrown primary roots are much larger than secondary (second-order) roots (Tomlinson 1990).

Our data are consistent with the later ones of Meerow (1992) and Broschat and Meerow (2000) for root ball size and suggest that root balls extending $30 \mathrm{~cm}$ (12 in.) out from the trunk are sufficient for transplanting because they capture about $50 \%$ or more of the roots. Even smaller root balls extending only $15 \mathrm{~cm}$ (6 in.) out from the trunk would be adequate for species that have $50 \%$ or more of their roots within this distance.

Our data also suggest that a root ball $30 \mathrm{~cm}$ (12 in.) deep would include most roots in most species. A deeper root ball (60 cm [24 in.] deep or more) would be advantageous for Butia capitata, Livistona chinensis, and Syagrus romanzoffiana to capture most of their roots. Consider root balls $60 \mathrm{~cm}$ (24 in.) or more deep for species with large number of roots (>30\%)
Table 5. Mean new root numbers and percentage (in parentheses, rounded to a whole number) of $16 \mathrm{palm}$ species by two depth zones and out to $90 \mathrm{~cm}$ from the trunk, The Los Angeles County Arboretum \& Botanic Garden, Arcadia, California, 1997-2000.

\begin{tabular}{lll}
\hline & \multicolumn{2}{c}{ Depth } \\
\cline { 2 - 3 } Species & $0-30 \mathrm{~cm}$ & $30-60 \mathrm{~cm}$ \\
\hline Archontophoenix cunninghamiana & $14.0 \mathrm{a}(72)$ & $5.6 \mathrm{~b}(29)$ \\
Brahea edulis & $5.7 \mathrm{a}(92)$ & $0.5 \mathrm{~b}(9)$ \\
Butia capitata & $8.5(53)$ & $7.6(47)$ \\
Caryota mitis & $21.4 \mathrm{a}(77)$ & $6.5 \mathrm{~b}(23)$ \\
Chamaerops humilis & $14.4 \mathrm{a}(76)$ & $4.6 \mathrm{~b}(24)$ \\
Livistona chinensis & $15.0(53)$ & $13.5(48)$ \\
Livistona decipiens & $66.6 \mathrm{a}(84)$ & $13.0 \mathrm{~b}(16)$ \\
Phoenix canariensis & $78.5 \mathrm{a}(80)$ & $18.9 \mathrm{~b}(20)$ \\
Phoenix reclinata & $77.7 \mathrm{a}(67)$ & $38.7 \mathrm{~b}(33)$ \\
Rhapidophyllum hystrix & $17.3 \mathrm{a}(64)$ & $9.7 \mathrm{~b}(36)$ \\
Sabal etonia & $16.4 \mathrm{a}(70)$ & $7.1 \mathrm{~b}(30)$ \\
Serenoa repens & $12.3 \mathrm{a}(73)$ & $4.5 \mathrm{~b}(27)$ \\
Syagrus romanzoffiana & $49.8(50)$ & $50.5(50)$ \\
Trachycarpus fortunei & $45.8 \mathrm{a}(77)$ & $13.5 \mathrm{~b}(23)$ \\
Trachycarpus wagnerianus & $91.6 \mathrm{a}(97)$ & $2.5 \mathrm{~b}(3)$ \\
Washingtonia robusta & $116.5 \mathrm{a}(71)$ & $46.7 \mathrm{~b}(29)$ \\
\hline
\end{tabular}

Means in the same row followed by a different letter are significantly different according to paired t-tests between columns, $P<0.05$

in the 30 to $60 \mathrm{~cm}$ (12 to $24 \mathrm{in}$.) deep zone. A deeper root ball might also aid in stabilizing and anchoring the palm.

Although Broschat and Donselman (1984a, 1984b, 1990) concluded that maximum palm transplant success depends on the root ball being large enough to ensure that a maximum or high percentage of severed roots regrow, our 
findings support the concept that the total number of new roots that grow and their density, regardless of their origin, are the key factors in determining root ball size. Because rapid growth of a large number of new roots from the RIZ and/or from regrowth of severed roots is most critical to transplant success, in most cases root balls extending $30 \mathrm{~cm}$ (12 in.) out from the trunk are sufficiently large to ensure that this growth occurs.

Even if the ability of severed roots to regrow is critical to determining root ball size, the total number of roots that regrow might be more important than the percentage of roots that regrow. For example, Broschat and Donselman (1984a, 1984b) reported that Cocos nucifera generally had $50 \%$ of cut roots regrow regardless of distance from the trunk. However, there were so few roots beyond $30 \mathrm{~cm}(12$ in.) from the trunk in their study (only 14 out of a total of 160 regrown roots in all zones combined) that the high rate of regrowth in that area is irrelevant. In C. nucifera, Roystonea regia, and Syagrus romanzoffiana, the distance from the trunk at which $30 \%$ of roots regrew actually did encompass nearly a third or more of the total number of regrown roots in all the zones combined. Unfortunately, Broschat and Donselman (1990) reported only percentages of regrown roots, not actual numbers, for Phoenix reclinata and Washingtonia robusta.

In many instances, the ability of severed palm roots to regrow might be more apparent than real. While we observed that most severed roots did not regrow at the cut point, neither did they always die. Some severed roots remained alive and appeared to be functional. Also, some severed roots that appeared to die did so only for a short distance and actually regrew into the trench from several centimeters proximal of the cut. When these regrown severed roots entered the trench, they appeared like new roots from the RIZ. Unless each root entering the trench is traced back to its origin, it is impossible to determine whether the root grew from the RIZ or from a severed root. Hodel and Pittenger (2003) showed that most severed roots of Phoenix dactylifera offshoots regrew, often within $2 \mathrm{~cm}$ (0.8 in.) of the trunk, but appeared as new roots from the RIZ when they emerged from the root ball. Thus, many of the roots reported as growing from the RIZ in earlier studies likely regrew from severed roots.

\section{Root Pruning}

Although they provided no supporting data, Broschat and Donselman (1984a, 1984b, 1987, 1990) stated that root pruning 1 to 3 months prior to transplanting would grow a new root system faster because it stimulates new roots to grow from the RIZ prior to moving the palm, thus minimizing transplant shock. However, palm root growth is greatest during the warmer times of the year when soil and air temperatures are highest and, that in tropical areas and southern Florida, root growth is frequent and regular yearround (Broschat 1998). Thus, it is likely that the root growth from the RIZ in their studies was in response to the warm soil and air temperatures rather than the cutting of roots.

Broschat and Donselman (1987) also concluded that root pruning would benefit even species that produce most of their new roots from regrowth of severed roots because it would shorten or even eliminate the length of time for the cut roots to regrow after transplanting. More recently, Meerow (1992) and Broschat and Meerow (2000) placed less emphasis on root pruning but said it might be useful in some cases. Harris et al. (2004) also supported the practice. Even if root pruning does provide these positive benefits, there is still a serious concern with this practice because any new roots that grow from the RIZ or regrow from roots severed during pruning will be highly susceptible to damage during the digging, transporting, and replanting processes. After root pruning, transplanting too early might lose the purported benefit of this practice, while waiting too long to transplant might damage any new roots that had grown. Thus, we feel that root pruning palms prior to transplanting has little merit.

\section{SUMMARY AND CONCLUSIONS}

For many palm species, most roots occur within $30 \mathrm{~cm}$ (12 in.) of the trunk and, in Mediterranean climates, are produced most abundantly during the warmer months, especially in the summer. Palms need active root and shoot growth to establish quickly after transplanting. Palms can be transplanted year-round in warm regions where air and soil temperatures are nearly always sufficient to ensure adequate root and shoot growth. In contrast, palms are best transplanted at the beginning of the warm season in regions where air and soil temperatures are insufficient for adequate growth for several months of the year. Thus, the best time to transplant palms in Mediterranean climates is the late spring to early summer because this time provides a long, warm period that promotes root and shoot growth to ensure quick establishment.

Root balls with a $30 \mathrm{~cm}$ (12 in.) radius from the trunk and $30 \mathrm{~cm}$ (12 in.) deep are adequate for most palms when transplanting because this size captures well over half the roots. The few palms that must grow nearly all their new roots from the RIZ after transplanting need a root ball only big enough to protect the RIZ, about $15 \mathrm{~cm}$ (6 in.) out from the trunk. Palms that grow about $30 \%$ or more of their roots below $30 \mathrm{~cm}$ (12 in.) deep and exceptionally large specimens would probably benefit from a deeper root ball, about $60 \mathrm{~cm}$ (24 in.) deep. 


\section{LITERATURE CITED}

Broschat, T.K. 1998. Root and shoot growth patterns in four palm species and their relationships with air and soil temperatures. HortScience 33:995-998.

Broschat, T.K., and H. Donselman. 1984a. Root regeneration in transplanted palms. Principes 23:90-91.

- 1984b. Regrowth of severed palm roots. J. Arboric. 10:238-240.

. 1987. Factors affecting palm transplant success.

Proc. Fla. St. Hortic. Soc. 100:396-397.

_ 1990. Regeneration of severed roots in Washingtonia robusta and Phoenix reclinata. Principes 34:96-97.

Broschat, T.K., and A.W. Meerow. 2000. Ornamental Palm Horticulture. University Press of Florida, Gainesville, FL.

Donselman, H.M. 1981. Planting a Palm Tree. University of Florida IFAS, Cooperative Extension Service Fact Sheet ENH-46. Gainesville, FL.

Harris, R.W., J.R. Clark, and N.P. Matheny. 2004. Arboriculture: Integrated Management of Landscape Trees, Shrubs, and Vines (4th ed.). Prentice Hall. Upper Saddle River, NJ.

Hodel, D.R. 1995. An ounce of prevention. Am. Nurseryman 182(4):68-75.

_ 1996. Planting palms correctly for vigorous, attractive growth and fewer problems. Turf Tales 3(1):10-11.

. 1997. Planting palms. Grounds Maint. 32:C10-12.

Hodel, D.R. and D.R. Pittenger. 2003. Studies on the establishment of date palm (Phoenix dactylifera 'Deglet Noor') offshoots. Part I: Observations on root development and leaf growth. Palms 47:191-200.

Hodel, D.R., A.J. Downer, and D.R. Pittenger. 1998. Palm root regeneration, pp. 46-50. In Neely, D., and G.W. Watson (Eds.). The Landscape Below Ground II: Proceedings of an International Workshop on Tree Root Development in Urban Soils, 5-6 Mar. 1998, San Francisco, CA. International Society of Arboriculture, Champaign, IL.

Hodel, D.R., D.R. Pittenger, A.J. Downer, and W.E. Richie. 2003. Effect of leaf removal and tie up on juvenile, transplanted Canary Island date palms (Phoenix canariensis) and queen palms (Syagrus romanzoffiana). Palms 47:177184.
Meerow, A.W. 1992. Betrock's Guide to Landscape Palms. Betrock Information Services, Hollywood, FL.

Meerow, A.W., and T.K. Broschat. 1992. Transplanting Palms. University of Florida IFAS, Cooperative Extension Service Circular 1047. Gainesville, FL.

Pittenger, D.R, A.J. Downer, and D.R. Hodel. 2000. Palm root regeneration and its significance in transplanting. In Ranney, T.G. (Ed.). Proceedings of the 11th Conference of the Metropolitan Tree Improvement Alliance, 23-24 Aug. 2000, Gresham, OR. www.ces.ncsu.edu/fletcher/ programs/nursery/metria/metriall (accessed 5/19/05).

Tomlinson, P.B. 1961. Palmae, Vol. II., pp. 47-52. In Metcalfe, C.R. (Ed.). Anatomy of the Monocotyledons. Clarendon Press, Oxford, UK.

— 1990. The Structural Biology of Palms. Oxford University Press, Oxford, UK.

Acknowledgments. We thank The Los Angeles County Arboretum \& Botanic Garden in Arcadia, California, for permission to perform this study at their facility and Lori A. Yates for advice on statistical analysis.

1"Environmental Horticulture Advisor

University of California Cooperative Extension

4800 E. Cesar Chavez Ave.

Los Angeles, CA 90022, U.S.

drhodel@ucdavis.edu

${ }^{2}$ Area Environmental Horticulture Advisor

University of California, Cooperative Extension

Botany \& Plant Science

Riverside, CA 92521, U.S.

${ }^{3}$ Environmental Horticulture Advisor

University of California, Cooperative Extension

669 County Square Dr., $\# 100$

Ventura, CA 93003, U.S. 
Résumé. Les palmiers ont besoin d'une croissance active des racines et des pousses pour s'établir rapidement après la transplantation. Pour la plupart des espèces de palmiers, la croissance des racines doit être abondante durant les mois chauds et se faire dans les premiers $30 \mathrm{~cm}$ de distance du tronc. De ce fait, les palmiers peuvent être transplantés durant toute l'année dans les régions chaudes lorsque la température de l'air et du sol est à peu près suffisante pour assurer une croissance adéquate des racines et des pousses. Cependant, dans les régions avec une saison plus froide, les palmiers sont mieux d'être transplantés au début de la saison chaude. Pour la plupart des espèces, une motte de racines de $30 \mathrm{~cm}$ de rayon à partir du tronc et de $30 \mathrm{~cm}$ de profondeur est adéquate parce qu'elle contient plus de la moitié des racines. Les quelques espèces qui doivent produire la croissance de toutes leurs nouvelles racines à proximité immédiate du tronc lors de la transplantation n'ont besoin que d'une motte de racines suffisamment large pour protéger la zone d'initiation racinaire, soit environ $15 \mathrm{~cm}$ du tronc. Les espèces qui produisent $30 \%$ ou plus de leurs racines sous les 30 $\mathrm{cm}$ de profondeur bénéficieraient sans doute mieux d'une motte plus profonde, soit d'environ $60 \mathrm{~cm}$ de profondeur.

Zusammenfassung. Palmen brauchen aktive Wurzeln und Triebe, um sich nach der Verpflanzung schnell zu regenerieren. Bei den meisten Palmenarten wachsen die Wurzeln am besten während der warmen Monate und tauchen innerhalb von $30 \mathrm{~cm}$ vom Stamm auf. Daher können Palmen in warmen Regionen, die entsprechende Luft- und Wassertemperaturen bieten, das ganze Jahr über verpflanzt werden. In kühleren Regionen werden Palmen am besten zu Beginn der warmen Saison verpflanzt. Für die meisten
Arten sind Wurzelballen mit $30 \mathrm{~cm}$ Radius vom Stamm und $30 \mathrm{~cm}$ Tiefe angemessen, weil sie gut die Hälfte der Wurzelmasse enthalten. Die wenigen Arten, die nahezu all ihre Wurzeln nach der Verpflanzung neu bilden müssen, brauchen einen Wurzelballen, der grade so groß ist, um die Wurzelbildungszone zu bedecken, ca. 15 $\mathrm{cm}$ vom Stamm. Arten, die 30 \% oder mehr ihrer Wurzeln unterhalb von $30 \mathrm{~cm}$ Tiefe bilden, würden wahrscheinlich von einem tieferen $(60 \mathrm{~cm})$ Wurzelballen profitieren.

Resumen. Las palmeras necesitan un activo crecimiento de raíces y brotes para establecerse rápidamente después del trasplante. Para muchas especies de palmeras el crecimiento de las raíces es más abundante durante los meses más calientes y ocurre dentro de los $30 \mathrm{~cm}$ alrededor del tronco. Por lo tanto, las palmeras pueden ser trasplantadas todo el año en regiones calientes, donde las temperaturas del aire y del sol son suficientes para asegurar un adecuado crecimiento de las raíces y brotes. Sin embargo, en regiones con estaciones frías, las palmeras deben ser trasplantadas al principio de las estaciones calurosas. Para la mayoría de las especies, las bolas de raíces con un radio de $30 \mathrm{~cm}$ y $30 \mathrm{~cm}$ de altura son adecuadas porque ellas capturan más de las mitad de las raíces. Las pocas especies cuyas nuevas raíces deben crecer cerca del tronco después del trasplante, solo necesitan una bola lo suficientemente grande para proteger la zona de iniciación, cerca de $15 \mathrm{~cm}$ afuera del tronco. Las especies que crecen cerca del $30 \%$ o más de sus raíces debajo de los $30 \mathrm{~cm}$ de profundidad, deberán probablemente beneficiarse de una bola más profunda, con cerca de $60 \mathrm{~cm}$ de altura. 